\title{
REPRESENTASI HUKUM DALAM CERPEN HAKIM SARMIN KARYA AGUS NOOR: ANALISIS KONFLIK SOSIAL LEWIS A. COSER
}

\author{
Mega Tri Purnami, I Wayan Wendra, I Nyoman Yasa \\ Progam Studi Pendidikan Bahasa Indonesia \\ Universitas Pendidikan Ganesha \\ Singaraja, Indonesia \\ e-mail: \{purnamimega96@gmail.com,wayanwendra@yahoo.com, \\ keswa.kanaya@yahoo.com\}@undiksha.ac.id
}

\begin{abstract}
ABSTRAK
Penelitian ini bertujuan untuk mendeskripsikan (1) gambaran konflik hukum di Indonesia, (2) representasi hukum dalam cerpen Hakim Sarmin Karya Agus Noor, dan (3) relevansi fenomena hukum dalam cerpen Hakim Sarmin Karya Agus Noor dalam pembelajaran teks cerpen di SMA. Subjek dalam penelitian ini adalah cerpen Hakim Sarmin karya Agus Noor. Penelitian ini berjenis deskriptif dengan menggunakan pendekatan kualitatif. Data dalam penelitian ini dikumpulkan dengan metode dokumentasi. Dalam menganalisis data yang sudah dikumpulkan, peneliti menggunakan metode analisis deskriptif kualitatif. Langkah-langkah yang dilakukan dalam tahap analisis data, yakni reduksi data, penyajian data, dan penarikan simpulan. Hasil penelitian ini adalah (1) berita-berita terkait konflik hukum di Indonesia menggambarkan adanya ketidakadilan hukum di Indonesia. $\mathrm{Hal}$ tersebut tercermin melalui putusan pengadilan yang berat sebelah. Konflik yang tercermin dalam berita tersebut, yaitu konflik realistis dan konflik nonrealistis. Terdapat satu data konflik realistis dan satu data konflik nonrealistis, (2) cerpen Hakim Sarmin karya Agus Noor merepresentasikan ketidakadilan hukum yang terjadi di Indonesia. Terdapat tujuh data konflik sosial Lewis A. Coser dengan rincian dua data konflik realistis dan lima data konflik nonrealistis, (3) fenomena hukum dalam cerpen Hakim Sarmin karya Agus Noor relevan digunakan sebagai bahan ajar teks cerpen untuk siswa kelas XI SMA, karena memenuhi tiga kriteria aspek pemilihan bahan ajar sastra, yaitu aspek bahasa, psikologi, dan latar belakang budaya.
\end{abstract}

Kata Kunci: representasi hukum, cerpen hakim sarmin

\begin{abstract}
The research aimed to describe (1) the description of law conflicts in Indonesia, (2) law representation in the short story of Hakim Sarmin by Agus Noor, and (3) relevance of law phenomenon in the short story of Hakim Sarmin by Agus Noor of being used as teaching short story text learning in the Senior High School. The subjects in this research was the short story of Hakim Sarmin by Agus Noor. This research was descriptive type using a qualitative approach. The data in this study were collected by the documentation method. In analyzing the data that has been collected, researchers used a qualitative descriptive analysis method. The steps taken in the data analysis phase, namely data reduction, data display, and conclusion drawing/verification. The results of this research were (1) news regarding law conflicts in Indonesia is illustrates law injustice in Indonesia. This is reflected through a biased court ruling. The conflict is reflected in the news, namely realistic conflict and non-realistic conflict. There are one realistic data conflicts and one non-realistic conflict, (2) the short stories of Hakim Sarmin by Agus Noor represented law in that occurred in Indonesia. There are seven social conflict data by Lewis A. Coser with
\end{abstract}


two realistic conflicts data and five non-realistics conflicts data, (3) the law phenomenon in the short stories of Hakim Sarmin by Agus Noor is relevant as a teaching material for short story texts for class XI students of Senior High School, because it fulfills three criterias for the selection of literary teaching materials, namely language, psychology, and cultural background.

Keywords: law representation, hakim sarmin

\section{PENDAHULUAN}

Karya sastra tidak terlepas dari kehidupan sosial masyarakat, karena sastra merupakan perwakilan dari perasaan, pengalaman, gagasan, dan kenyataan hidup yang terjadi di masyarakat. Karya sastra merupakan cerminan dari kehidupan sosial. Karya sastra merupakan sebuah wadah (Yasa, 2012). Sebagai sebuah wadah, karya sastra menjadi alat untuk menampung ide-ide atau gagasan-gagasan penulis. Ide atau gagasan tersebut berangkat dari fenomena-fenomena sosial, politik, dan budaya yang terjadi di masyarakat.

Salah satu karya sastra yang menjadi wadah dalam menuangkan ideide atau gagasan-gagasan yang mencerminkan kehidupan sosial adalah cerpen. Cerpen merupakan salah satu bagian dari sastra imajinatif yang berupa prosa. Cerpen disebut sebagai cerita pendek bukan karena jumlah halamannya yang sedikit, tetapi karena alur cerita yang disajikan singkat, namun sampai pada penyelesaian. Dawud (2004: 141) menyatakan bahwa "cerpen adalah karangan singkat, sederhana, dan berisikan masalah tunggal yang habis dibaca sekali duduk saja".

Melalui karya sastra, pengarang mengungkapkan permasalahan yang terjadi di masyarakat. Dengan kata lain, karya sastra dibesarkan oleh permasalahan atau konflik yang terjadi di masyarakat. Suatu karya sastra seperti cerpen, jika tidak terdapat konflik, maka alur ceritanya akan terasa datar dan tidak indah. Hal ini akan berpengaruh pada minat pembaca dalam membaca karya sastra tesebut. Hal ini dikarenakan konflik memberikan gambaran tentang isi cerita, memberikan gambaran tentang bagus tidaknya suatu karya, dan juga memberikan gambaran secara jelas sifatsifat para tokohnya.

Dalam cerpen, ada berbagai konflik yang pengarang tuangkan, misalnya konflik politik, konflik sosial, konflik batin, dan lain sebagainya. Fokus pada penelitian ini adalah konflik sosial yang terdapat dalam salah satu cerpen Indonesia, yaitu cerpen Hakim Sarmin karya Agus Noor. Lebih spesifik lagi, penelitian ini difokuskan lagi pada analisis hukum yang dikaji dengan Teori Konflik Sosial Lewis A. Coser. "Konflik sosial secara sederhana dapat diartikan sebagai suatu proses sosial antara dua pihak atau lebih ketika pihak yang satu berusaha menyingkirkan pihak lain dengan cara menghancurkan atau membuatnya tidak berdaya" (Sayuti, 2000: 139). Latar belakang terjadinya konflik adalah karena adanya perbedaan pendapat, keyakinan, adat istiadat, dan lain sebagainya. Pemilihan konflik sosial dalam penelitian ini didasarkan pada jenis konflik yang terdapat pada dua cerpen tersebut. Konflik-konflik yang terjadi pada cerpencerpen tersebut disebabkan oleh paham hukum yang ditentang oleh penegak hukum, yang kemudian permasalahan hukum ini menimbulkan konflik antarindividu dan antarkelompok.

Coser (dalam Wulansari, 2009: 184) membedakan konflik yang realistis dari yang tidak realistis. Konflik yang realistis merupakan konflik yang berasal dari kekecewaan partisipan kepada objek yang dianggap mengecewakan serta karena adanya perkiraan keuntungan yang didapat oleh partisipan dari sasaran objek yang dianggap mengecewakan. Sedangkan, konflik yang tidak realistis merupakan konflik yang bukan berasal 
dari tujuan-tujuan antagonis, tetapi karena adanya kebutuhan untuk meredakan ketegangan, paling tidak dari salah satu pihak. Dua tipe konflik sosial yang diutarakan oleh Coser tersebut terdapat dalam cerpen Hakim Sarmin karya Agus Noor, sehingga Teori Konflik Sosial Lewis A. Coser relevan digunakan untuk menganalisis cerpen tersebut.

Dalam kehidupan sosial masyarakat, hukum merupakan hal yang sangat penting. Ketika hukum tidak berjalan sesuai aturan, hal tersebut akan mengganggu tatanan keharmonisan masyarakat. Pengkriminalitasan hukum yang terjadi dapat menjadi sebab terjadinya berbagai konflik yang kemudian akan menimbulkan kehancuran negara. Carut-marutnya hukum di Indonesia terepresentasikan di dalam karya sastra Indonesia.

Sesungguhnya, banyak karya sastra yang merepresentasikan hukum di Indonesia, tetapi yang paling proporsional datanya adalah cerpen Hakim Sarmin karya Agus Noor. Cerpen tersebut menceritakan tentang kecurangankecurangan penegak hukum dalam melakukan pekerjannya. Perilaku penegak hukum tersebut kemudian menyebabkan konflik yang tidak terhindarkan, baik antar masyarakat dengan penegak hukum tersebut maupun dengan pihak lain. Cerita dalam cerpen tersebut mampu merepresentasikan lemahnya hukum di Indonesia yang mengakibatkan terjadinya konflik sosial.

Cerpen Hakim Sarmin bisa digunakan oleh guru sebagai materi pembelajaran menganalisis unsur-unsur pembangun cerita pendek. Hal tersebut sesuai dengan silabus kompetensi dasar (KD) 3.9, yaitu "menganalisis unsur-unsur pembangun cerita pendek dalam buku kumpulan cerita pendek yang dibaca".kelas XI kurikulum 2013. Namun, sebelumnya teks tersebut harus dianalisis kesesuaian isinya sebagai bahan ajar dengan siswa. Menurut Rahmanto (dalam Hermanda, 2018) ada tiga aspek bahan pengajaran, yaitu (1) kebahasaan, (2) psikologi, dan (3) latar belakang budaya.

Cerpen Hakim Sarmin karya Agus Noor dapat dijadikan sebagai bahan ajar dalam pembelajaran teks cerpen, karena mengangkat tentang fenomena hukum yang hal tersebut merupakan fenomena yang sering dibicarakan di kehidupan sosial masyarakat, sehingga tentunya dekat dengan latar belakang sosial budaya siswa sebagai pembaca. Hal ini sesuai dengan konsep belajar kontekstual yang sangat penting bagi siswa. "Metode pembelajaran kontekstual merupakan konsep pembelajaran yang membantu guru mengaitkan antara materi yang diajarkan dengan situasi dunia nyata siswa yang mendorong siswa membuat hubungan antara pengetahuan yang dimilikinya dengan penerapan dalam kehidupan mereka sebagai anggota keluarga atau masyarakat" (Depdiknas dalam Ulum, 2015). Hal tersebut akan mempermudah siswa dalam memahami jalan pesan yang disampaikan penulis dalam cerpen.

Tujuan penelitian ini adalah untuk mendeskripsikan (1) gambaran konflik hukum di Indonesia, (2) representasi hukum dalam cerpen Hakim Sarmin Karya Agus Noor, dan (3) relevansi fenomena hukum dalam Hakim Sarmin Karya Agus Noor dalam pembelajaran teks cerpen di SMA.

Hasil penelitian ini diharapkan dapat memberikan manfaat kepada beberapa pihak, baik teoretis maupun praktis. Penelitian ini secara teoretis diharapkan dapat memberikan kontribusi bagi hasanah penelitian sastra, khususnya model telaah karya sastra dari segi representasi hukum yang menimbulkan konflik sosial yang terdapat di dalam karya sastra. Secara lebih spesifik, penelitian ini diharapkan mampu memberikan kontribusi terhadap kajian atau studi Konflik Sosial Lewis A. Coser dalam karya fiksi cerpen. Secara praktis, penelitian ini diharapkan dapat bermanfaat bagi beberapa pihak, yaitu 
bagi peneliti sendiri, guru, pembaca umum, dan peneliti lain.

\section{METODE PENELITIAN}

Rancangan penelitian yang digunakan dalam penelitian ini adalah rancangan deskriptif kualitatif. Wendra (2017) menyatakan bahwa subjek penelitian adalah sumber data di mana data penelitian diperoleh. Subjek penelitian ini adalah cerpen Hakim Sarmin karya Agus Noor, sedangkan objek penelitian ini adalah representasi hukum yang terdapat dalam dalam cerpen Hakim Sarmin karya Agus Noor yang dikaji dengan Teori Konflik Sosial Lewis A. Coser serta relevansi fenomena hukum dalam cerpen Hakim Sarmin karya Agus Noor dalam pembelajaran teks cerpen di SMA. Metode pengumpulan data yang digunakan dalam penelitian ini adalah metode dokumentasi. Dokumen yang dimaksud adalah berita-berita dari media massa sebagai data untuk mendeskripsikan gambaran konflik hukum di Indonesia, cerpen Hakim Sarmin karya Agus Noor untuk merepresentasikan hukum dalam cerpen terebut, dan silabus untuk mengetahui kesesuaian atau relevansi fenomena hukum dalam cerpen tersebut dalam pembelajaran teks cerpen di SMA. Sejalan dengan metode pengumpulan data yang digunakan, yaitu metode dokumentasi, maka dalam penelitian ini digunakan instrumen penelitian berupa kartu data. Dalam menganalisis data yang sudah dikumpulkan, peneliti menggunakan metode analisis deskriptif kualitatif, sehingga langkah-langkah yang dilakukan dalam tahap ini, yakni reduksi data (data reduction), penyajian data (data display), dan penarikan simpulan (conclusion drawing/verification).

\section{HASIL DAN PEMBAHASAN}

Terdapat tiga hasil dalam penelitian ini. Pertama, terkait gambaran konflik hukum di Indonesia. Kedua, terkait representasi hukum dalam cerpen Hakim
Sarmin karya Agus Noor. Ketiga, terkait relevansi fenomena hukum dalam cerpen Hakim Sarmin karya Agus Noor dalam pembelajaran teks cerpen di SMA.

Pertama, terkait gambaran konflik hukum di Indonesia. Konflik hukum di Indonesia menggambarkan adanya ketidakadilan hukum di Indonesia. Hal ini nampak dari berita-berita terkait kasus yang terjadi di Indonesia, yaitu dipaparkan sebagai berikut.

Berita berjudul 25 Terdakwa Korupsi Miliaran Rupiah Divonis Bebas diterbitkan oleh KOMPAS.com pada Kamis, 14 Januari 2010. Berita tersebut memuat informasi tentang 25 terdakwa kasus korupsi di Jawa Tengah selama tahun 2009 mendapat vonis bebas dan lepas dari pengadilan, sedangkan dua terdakwa lainnya divonis hukuman percobaan. Modus majelis hakim dalam memberikan vonis bebas terhadap terdakwa kasus korupsi dengan mengalihkan pertanggungjawaban pidana ke ranah administratif.

"Menurut Eko, keputusan majelis hakim tersebut aneh dan tidak masuk akal karena pelanggaran administratif termasuk dalam pelanggaran hukum sehingga termasuk perbuatan melawan hukum." (regional.kompas.com).

Adapun terdakwa kasus korupsi yang mendapat vonis bebas itu, antara lain terdakwa kasus dugaan korupsi pengadaan alat medis Kabupaten Banjarnegara pada 2006, yaitu Direktur PT Dharma Mulia Multi Farma Semarang, Heri Prabowo, dengan jumlah Rp 2,9 miliar. Selain itu, ada Sembilan anggota DPRD Solo yang menjadi terdakwa kasus korupsi APBD 2003 sebesar Rp 4,2 miliar.

Melalui berita tersebut, dapat diketahui bahwa yang melakukan korupsi adalah orang-orang yang memiliki jabatan yang tinggi dan penting. Jumlah uang yang dikorupsi pun tidaklah sedikit. Tindakan tersebut melanggar tata tertib 
hukum di Indonesia, sehingga pelakupelakunya harus dihukum sesuai dengan tindakannya. Namun, pada kenyataannya hakim membebaskan pelaku-pelaku tersebut dari dakwaan yang diberikan. Keputusan tersebut dianggap aneh dan tidak masuk akal.

Dalam berita tersebut, dapat dilihat pula adanya penentangan dari Eko yang merupakan Sekretaris Komite Penelidikan Pemberantasan Korupsi Kolusi Nepotisme (KP2KKN) terhadap putusan majelis hakim yang membebaskan 25 terdakwa korupsi. Penentangan tersebut merupakan cerminan dari adanya konflik realistis. Konflik yang realistis berasal dari kekecewaan terhadap tuntutan-tuntutan khusus yang terjadi dalam hubungan dan dari perkiraan kemungkinan keuntungan para partisipan yang ditunjuk pada objek yang dianggap mengecewakan (Wulansari, 2009).

Berita yang berjudul Mencuri 3 Buah Kakao, Nenek Minah Dihukum 1 Bulan 15 Hari diterbitkan oleh detiknews pada Kamis, 19 November 2009. Kasus dalam berita tersebut bermula dari tindakan Nenek Minah yang memetik tiga buah kakao di perkebunan milik PT Rumpun Sari Antan (RSA) yang kemudian diketahui oleh mandor perkebunan tersebut. Sadar tindakannya salah, Minah meminta maaf dan berjanji tidak akan melakukannya lagi. Namun, kasus tersebut tersebut ternyata berbuntut ke meja hijau atas dakwaan pencurian. Majelis hakim memvonisnya 1 bulan 15 hari dengan masa percobaan selama 3 bulan. Minah dinilai terbukti secara sah dan meyakinkan melanggar pasal 362 KUHP tentang pencurian.

"Selain menghadirkan nenek yang miskin sebagai terdakwa, majelis hakim juga terlihat ragu menjatuhkan hukum. Bahkan ketua majelis hakim, Muslih Bambang Luqmono $\mathrm{SH}$, terlihat menangis saat membacakan vonis." (detik.com).
Berita tentang Nenek Minah yang mencuri tiga buah kakao merupakan cerminan dari ketidakmampuan rakyat kecil untuk melawan ketidakadilan hukum. Bila kembali melihat pada kasus sebelumnya, jumlah kerugian yang dialami oleh korban pencurian dari kedua kasus tersebut sangat jauh di bawah jumlah uang yang dikorupsi oleh para pejabat. Namun, penanganan hukum antara pelaku korupsi yang mencuri uang rakyat hingga miliaran rupiah tidak sebanding dengan pelaku pencurian dengan jumlah kerugian hanya puluhan ribu rupiah. Hal tersebut tidak sejalan dengan tujuan hukum yang dikemukakan oleh L.J. van Apeldoorn (dalam Is, 2015), yaitu untuk mengatur pergaulan hidup secara damai karena hukum menghendaki perdamaian, atau mengatur tata tertib dalam masyarakat secara damai dan adil.

Berdasarkan teori konflik sosial Lewis A. Coser, majelis hakim dan ketua majelis hakim dalam berita tersebut merupakan orang yang menjadi kambing hitam dalam konflik antara pihak PT RSA dan Nenek Minah. Objek kekecewaan pihak PT RSA adalah Nenek Minah, namun yang mengalami keraguan juga tangisan adalah pihak majelis hakim.

Berita-berita tersebut menunjukkan adanya ketidakadilan hukum di Indonesia yang tercermin melalui putusan pengadilan yang berat sebelah. Pengadilan terlalu berfokus pada substansi hukum tanpa mempertimbangkan aspek yang lain. Konflik yang tercermin dalam berita tersebut adalah konflik realistis dan konflik nonrealistis. Terdapat satu data konflik realistis dan satu konflik nonrealistis. Hal tersebut menunjukkan adanya kecenderungan konflik realistis lebih sering terjadi dalam konflik hukum di Indonesia.

Kedua, terkait representasi hukum dalam cerpen Hakim Sarmin karya Agus Noor. Dari hasil analisis, ditemukan bahwa cerpen Hakim Sarmin karya Agus 
Noor merepresentasikan ketidakadilan hukum yang terjadi di Indonesia. Dalam cerpen tersebut terdapat konflik realistis dan konflik nonrealistis. Hal tersebut tercermin dalam data berikut.

"Konflik yang realistis berasal dari kekecewaan terhadap tuntutan-tuntutan khusus yang terjadi dalam hubungan dan dari perkiraan kemungkinan keuntungan para partisipan yang ditunjuk pada objek yang dianggap mengecewakan" (Wulansari, 2009: 185). Konflik tersebut bisa terjadi antarkelompok maupun antarindividu. Berikut kutipan pada cerpen Hakim Sarmin yang berkaitan dengan representasi hukum yang diklasifikasikan ke dalam konflik realistis.

"[...] Siapa pun tak akan menyangka ia membunuh lima lelaki, setelah menyimpan dendamnya begitu lama. [...]" (HS: 33)

Data di atas menunjukkan adanya pelanggaran hukum yang dilakukan oleh seorang perempuan. Pelanggaran hukum tersebut berupa sebuah tindak kejahatan, yaitu pembunuhan. Perempuan tersebut menyimpan dendam karena pernah diperkosa oleh kelima lelaki tersebut, sehingga ia melakukan pembunuhan. Hal tersebut menunjukkan adanya sebuah konflik yang terjadi antara perempuan tersebut dan kelima lelaki yang dibunuh. Konflik yang terjadi dapat membawa perempuan tersebut ke ranah hukum, karena dalam menyelesaikan konflik, ia melakukan pelanggaran hukum.

$$
\text { Selain karena dendam, }
$$

perempuan tersebut meyakini bahwa membunuh merupakan jalan terbaik untuk memberikan hukuman yang setimpal kepada lelaki-lelaki yang sudah memperkosanya. la menuntut keadilan melalui pembunuhan bukan melalui jalur hukum, karena ia percaya bahwa keadilan akan ia dapatkan dari pembalasan dendam, bukan hukum. Hal tersebut tercerminkan pada kutipan berikut.
"[...] Dalam kebisuannya ia seakan ingin menegaskan: dendam adalah jalan terbaik untuk mendapatkan keadilan. Dan hukum yang buruk membuat orang lebih percaya pada dendam. [...]" (HS: 34)

Dari kutipan tersebut, dapat diketahui bahwa alasan perempuan tersebut tidak memilih jalur hukum dalam menyelesaikan konfliknya dengan kelima lelaki yang sudah memperkosanya adalah karena ia percaya bahwa ia tidak akan mendapatkan keadilan melalui hukum. Hukum yang ia ketahui adalah hukum yang buruk, sehingga ia lebih memilih membalaskan dendamnya dengan membunuh orang-orang yang sudah memperkosanya.

Dendam perempuan tersebut pada akhirnya menimbulkan hasrat untuk melakukan pembalasan dendam dengan membunuh orang-orang yang sudah memperkosanya. Hal tersebut menggambarkan keadaan di mana seseorang tidak melepaskan prasangka mereka melawan kelompok yang benarbenar merupakan lawan, sehingga menggunakan kelompok pengganti sebagai objek prasangka (Linggar, 2017: 4).

Selain konflik realistis, dalam cerpen Hakim Sarmin juga terdapat konflik nonrealistis. Berikut kutipan yang berkaitan dengan representasi hukum yang diklasifikasikan ke dalam konflik nonrealistis.

"Hakim Sarmin telah menangani bermacam perkara berat, tapi ini akan menjadi yang terberat dalam karirnya. la pernah mengalami tekanan ketika menangani kasus korupsi seorang Jenderal polisi bintang tiga. Pada mulanya, ia merasa bangga karena dipercaya menjadi hakim yang menyidangkan Jenderal polisi. la merasa, itu adalah batu lompatan terbesar dalam karirnya. Sampai 
kemudian ia menyadari, ia ternyata hanya dikorbankan; karena seperti Tuhan yang bekerja dengan cara rahasia, dalam hukum ada tangantangan tak terlihat yang bisa mengatur hasil akhir perkara. Nyaris tiap hari ia menjadi bahan ledekan dan lelucon di koran dan televisi ketika ia membebaskan Jenderal itu dari semua tuntutan. Lelucon terbesar dalam penegakan hakim, begitu koran dan televisi menyebut keputusannya. Hakim kini lebih lucu dari pelawak, komentar lainnya." (HS: 35)

Dari kutipan tersebut, dapat diketahui bahwa dalam kasus korupsi yang dilakukan oleh Jenderal polisi, terjadi kecurangan atau pengkriminalitasan hukum yang dilakukan oleh oknum-oknum yang ingin membebaskan Jenderal polisi tersebut meski sudah diketahui ia bersalah. Pelaku korupsi dibiarkan bebas dari hukuman yang harus diterimanya. Hal tersebut bertolak belakang dengan fungsi hukum sebagai sarana sosial kontrol yang dikemukakan oleh Asyhadie dan Arief (2016), bahwa hukum sebagai sarana sosial kontrol (social control) bertujuan untuk memberikan suatu batasan tingkah laku masyarakat yang menyimpang, dan akibat yang akan diterimanya karena penyimpangannya tersebut.

Kasus tersebut merupakan fenomena yang serupa dengan kasus yang pernah terjadi di Indonesia, yaitu tercermin pada berita yang berjudul 25 Terdakwa Korupsi Miliaran Rupiah Divonis Bebas yang peneliti bahas pada subbab sebelumnya. Kesamaan tersebut terletak pada status sosial pelaku korupsi. Pada cerpen dan berita tersebut menunjukkan pelaku korupsi adalah orang-orang yang memiliki jabatan tinggi. Selain itu, pelaku korupsi yang ada pada berita dan pada cerpen tersebut sama-sama dibebaskan dari hukuman.
Dalam kasus pada cerpen tersebut, yang dikorbankan atau dijadikan kambing hitam adalah Hakim Sarmin, sehingga konsekuensi yang didapat oleh Hakim Sarmin adalah ledekan yang dimuat dalam media massa. Berita-berita mengenai Hakim Sarmin yang dimuat di koran dan televisi tersebutlah yang mengundang pendapat masyarakat tentang ketidakadilan hukum.

Melalui peristiwa yang digambarkan dalam kutipan tersebut, dapat diketahui bahwa adanya kesadaran dari Hakim Sarmin bahwa sebenarnya ia sudah dikorbankan dalam kasus tersebut. Setelah mengadili seorang Jenderal polisi yang melakukan korupsi, yang kemudian berakhir dengan pembebasan Jenderal polisi tersebut, Hakim Sarmin menjadi bahan ejekan di media massa. Dengan terjadinya konflik tersebut, Hakim Sarmin pun menyadari bahwa hasil akhir di pengadilan dapat direkayasa oleh oknumoknum tertentu. Kesadaran tersebut yang kemudian mengubah sikap Hakim Sarmin dalam menangani kasus-kasus selanjutnya dengan hati-hati.

Dalam kasus lain, tergambarkan bahwa alasan pelanggaran hukum terjadi tidak dipertimbangkan di mata hukum. Hal tersebut dapat dilihat pada kutipan berikut.

\section{"[...] Pernah Hakim sarmin mengadili seorang nenek berumur 70 tahun yang mencuri sebungkus biskuit di minimarket. Selama persidangan nenek itu terus menangis dan mengiba, meratap dan bahkan bersujud minta ampun. la terpaksa mencuri biskuit itu untuk cucunya yang masih bayi dan sudah dua hari tak makan. Hakim Sarmin selalu teringat pada mata tak berdaya nenek tua itu ketika akhirnya ia memvonis dua tahun penjara." (HS: 37)}

Pada data tersebut, dapat diketahui bahwa di mata hukum, pelanggar hukum tetap harus dihukum 
meski tindak pelanggaran yang dilakukan tidaklah berat. Hal tersebut berbanding terbalik dengan kasus korupsi yang dilakukan oleh Jenderal polisi yang akhirnya dibebaskan. Pencurian sebungkus roti yang jumlah kerugiannya tidak akan bisa melampaui uang yang dikorupsi oleh Jenderal polisi tersebut harus berakhir dengan vonis dua tahun penjara.

Adanya perbedaan perlakuan yang diberikan di dalam pengadilan, seakanakan kedudukan atau jabatan seseorang akan memengaruhi perlakuan yang akan didapatkan, sehingga hal tersebut mencerminkan adanya ketidakadilan dalam penanganan kasus. Hal ini bertolak belakang dengan fungsi hukum sebagai sarana penyelesaian sengketa yang dikemukakan oleh Asyhadie dan Arief (2016), bahwa tujuan hukum pada dasarnya adalah untuk mencapai keadilan dalam menyelesaikan konflik di masyarakat maupun dalam melakukan pengendalian sosial. Hal tersebut menunjukkan adanya ketidakadilan dalam pengadilan.

Dalam konteks konflik nonrealistis, cucu nenek tersebut menjadi kambing hitam, karena dijadikan sebagai alasan agar kasus tersebut dapat dipertimbangkan. Dengan menyertai cucunya ke dalam kasus tersebut, diharapkan hal tersebut akan menyelesaikan konflik.

Kasus pada cerpen tersebut merepresentasikan peristiwa-peristiwa dalam fenomena hukum di Indonesia. Contoh kasus serupa adalah berita yang berjudul Mencuri 3 Buah Kakao, Nenek Minah Dihukum 1 Bulan 15 Hari dan Curi Sandal Polisi Seharga Rp 30 Ribu, Pelajar Terancam 5 Tahun Bui. Kasus nenek yang mencuri biskuit yang diceritakan dalam cerpen tersebut memiliki kesamaan dengan kedua berita yang peneliti bahas pada subbab Gambaran Hukum di Indonesia. Jumlah kerugian atas pencurian tersebut hanya puluhan ribu rupiah, namun hal tersebut tidak dipertimbangkan oleh hakim.

Dari hasil analisis tersebut, dapat diketahui bahwa cerpen Hakim Sarmin karya Agus Noor merepresentasikan ketidakadilan hukum yang terjadi di Indonesia. Terdapat sembilan belas data konflik sosial Lewis A. Coser dengan rincian delapan data konflik realistis dan sebelas data konflik nonrealistis. Hal tersebut menunjukkan bahwa konflik nonrealistis cenderung lebih banyak menggambarkan konflik di dalam cerpen. Cerpen tersebut merefleksikan pristiwaperistiwa hukum yang terjadi di Indonesia yang tercermin dari adanya kesamaan peristiwa hukum dalam cerpen dengan kenyataan yang terjadi di Indonesia. Ketidakadilan petugas-petugas hukum dalam menangani kasus yang diceritakan dalam cerpen tersebut juga terjadi dalam kehidupan nyata.

Ketiga, terkait relevansi fenomena hukum dalam cerpen Hakim Sarmin karya Agus Noor dalam pembelajaran teks cerpen di SMA. Fenomena hukum dalam cerpen Hakim Sarmin relevan dalam pembelajaran teks cerpen di SMA. Hal tersebut ditunjukkan melalui kutipan berikut.

\section{a. Aspek Bahasa}

\section{Cerpen}

Hakim

Sarmin menggunakan bahasa Indonesia baku, sehingga mudah untuk dimengerti. Meskipun cerpen tersebut membicarakan tentang hukum, namun tidak terdapat istilah-istilah hukum yang kompleks. Dalam cerpen tersebut tidak terdapat ragam bahasa daerah atau istilah-istilah yang kurang lazim didengar. Namun, dalam cerpen tersebut menggunakan bahasa kiasan. Hal tersebut ditunjukkan melalui kutipan berikut.

"[...] Bibir, pipi dan alisnya yang tanpa riasan seolah tak tersentuh dosa. Hanya matanya yang gelap dan keruh, seperti biji salak 
Ifenomenat, tapi dengan sorot tajam, membuat siapa pun yang menatapnya akan cepat-cepat mencari cara untuk menghindar. [...]" (HS: 33)

Pada kutipan tersebut, pengarang menggambarkan kondisi seseorang melalui perbandingan. Kondisi yang digambarkan pada kutipan tersebut, yaitu wajah perempuan tanpa riasan sama sekali. Kemurnian wajah perempuan tersebut dibandingkan dengan seseorang yang suci, bersih dari dosa. Mata perempuan tersebut digambarkan seperi biji salak yang Ifenomenat, yang menandakan bahwa mata perempuan tersebut sudah berkerut. Untuk mengetahui makna dari kiasan-kiasan tersebut dapat dengan mencari tahu keadaan benda yang menjadi perbandingan.

Dalam cerpen Hakim Sarmin terdapat beragam gaya bahasa yang digunakan oleh pengarang. Hal tersebut sesuai dengan sesuai dengan KD 3.9 (menganalisis unsur-unsur cerita pendek dalam buku kumpulan cerita pendek) pada silabus kelas XI. Gaya bahasa merupakan salah satu unsur pembangun cerita pendek, sehingga hal tersebut sesuai dengan pembelajaran siswa pada materi teks cerpen.

\section{b. Aspek Psikologi}

Cerpen Hakim Sarmin relevan digunakan oleh siswa kelas XI SMA. Pada tingkat tersebut, psikologi siswa berada pada tahap Generalisasi (16 tahun dan selanjutnya). Pada tahap ini, siswa tidak lagi berminat pada cerita-cerita fantasi, tetapi lebih berminat untuk menemukan konsep-konsep abstrak dengan menganalisis suatu fenomena. Dengan menganalisis fenomena, mereka berusaha menemukan dan merumuskan penyebab utama fenomena itu yang kadang-kadang mengarah ke pemikiran filsafat untuk menemukan keputusan moral.
Pada aspek ini, kegiatan membaca yang dilakukan siswa akan menstimulus siswa untuk mencari tahu sebab sebuah fenomena terjadi. Hal tersebut akan membantu siswa untuk memakanai nilainilai yang terkandung dalam cerpen dan menerapkannya dalam kehidupan seharihari. Hal tersebut tercermin pada kutipan berikut.

"[...] Siapa pun tak akan menyangka ia membunuh lima lelaki, setelah menyimpan dendamnya begitu lama. [...]" (HS: 33)

Pada data di atas, dapat diketahui bahwa melakukan tindak kejahatan kepada orang lain akan menimbulkan dendam. Apabila tindak kejahatan tersebut tidak ditangani oleh pihak yang berwenang akan memancing korban untuk melakukan pembalasan terhadap tindak kejahatan tersebut dengan tindak kejahatan pula.

Kutipan tersebut menunjukkan adanya konflik realistis pada cerpen Hakim Sarmin. "Konflik yang realistis berasal dari kekecewaan terhadap tuntutan-tuntutan khusus yang terjadi dalam hubungan dan dari perkiraan kemungkinan keuntungan para partisipan yang ditunjuk pada objek yang dianggap mengecewakan" (Wulansari, 2009: 185). Dendam merupakan sebuah gambaran dari kebencian perempuan tersebut terhadap tindakan lima orang lelaki yang memperkosanya. Kebencian tersebut kemudian menciptakan keinginan untuk membalaskan dendam, sehingga menimbulkan konflik yang lebih besar, yaitu tindak kriminalitas berupa pembunuhan.

Sebuah dendam memiliki jalan keluar lain untuk dibalaskan. Melalui hukum, pelaku tindak kejahatan akan mendapatkan hukuman yang setimpal, sehingga pembalasan dendam melalui tindak kejahatan tidak boleh dilakukan. 
Berikut adalah kutipan yang sesuai dengan pernyataan tersebut.

"Keadilan tak akan pernah terpuaskan oleh dendam karena itulah hukum diperlukan. [...]" (HS: 38)

Pada kutipan tersebut, dapat diketahui bahwa untuk mendapatkan keadilan, tidak dapat dilakukan dengan pembalasan dendam. Tujuan hukum adalah mengatur tata tertib dan kebebasan dalam bermasyarakat untuk menciptakan keadilan, keseimbangan, kedamaian, dan keamanan. Korban tindak kejahatan juga dinyatakan bersalah karena melakukan tindak kejahatan juga. Melalui hukum, diharapkan keadilan yang dikejar oleh korban dapat tercapai.

Nilai yang dapat ditarik dari peristiwa tersebut adalah berani mempertanggungjawabkan tindakan yang sudah dilakukan. Hukum merupakan sesuatu yang sah di sebuah negara, sehingga melalui hukum, diharapkan keadilan dapat tercapai tanpa dengan melakukan pembalasan dendam yang akan merugikan banyak pihak.

Cerpen Hakim Sarmin dapat digunakan sebagai bahan pembelajaran teks cerpen di SMA, karena fenomena hukum yang diceritakan dalam cerpen tersebut merupakan hal yang realistis. Cerpen Hakim Sarmin menyuguhkan peristiwa yang mencerminkan kenyataan yang terjadi di masyarakat. Peristiwaperistiwa dalam cerpen tersebut merupakan representasi dari peristiwa riil, artinya peristiwa yang digambarkan dalam cerpen tersebut bukan cerita fantasi. Siswa SMA kelas XI sebagai sasaran pembaca yang ingin dijangkau dalam penelitian ini berada pada tahap Generalisasi, yaitu tahap yang tidak lagi berminat pada bahan bacaan sastra yang bersifat fantasi.

Dalam cerpen Hakim Sarmin menyajikan fenomena-fenomena hukum yang sering terjadi di masyarakat. Hal tersebut penting untuk menyesuaikan bahan ajar dengan tahap siswa kelas XI yang berada pada tahap Generalisasi, seperti yang dikemukakan oleh Rahmanto (dalam Hermanda, 2018), yaitu dengan menganalisis fenomena, mereka berusaha menemukan dan merumuskan penyebab utama fenomena itu yang kadang-kadang mengarah ke pemikiran filsafat untuk menemukan keputusan moral. Dengan begitu, melalui fenomenafenomena hukum dalam cerpen Hakim Sarmin, siswa dapat menemukan nilainilai yang terkandung di dalamnya dan dapat menerapkannya dalam kehidupan bermasyarakat. Siswa dapat menemukan nilai moral yang terkandung dalam cerpen tersebut melalui penggambaran fenomena hukum yang penuh dengan kecurangan serta menerapkannya dalam kehidupan bermasyarakat. Hal tersebut sesuai dengan KD 3.8 (mengidentifikasi nilai-nilai kehidupan yang terkandung dalam kumpulan cerita pendek yang dibaca) dan KD 4.8 (mendemonstrasikan nilai kehidupan yang dipelajari dalam cerita pendek) pada silabus kelas XI.

\section{c. Aspek Latar Belakang Budaya}

Cerpen Hakim Sarmin menyuguhkan peristiwa-peristiwa yang terjadi di Indonesia, sehingga akan dekat dengan latar belakang budaya siswa. Hal tersebut digambarkan melalui kutipan berikut.

\section{“[...] Pernah Hakim sarmin mengadili seorang nenek berumur 70 tahun yang mencuri sebungkus biskuit di minimarket. Selama persidangan nenek itu terus menangis dan mengiba, meratap dan bahkan bersujud minta ampun. la terpaksa mencuri biskuit itu untuk cucunya yang masih bayi dan sudah dua hari tak makan. Hakim Sarmin selalu teringat pada mata tak berdaya nenek tua itu ketika akhirnya ia memvonis dua tahun penjara." (HS: 37)}


Berdasarkan kutipan di atas, dapat diketahui bahwa peristiwa tersebut serupa dengan peristiwa pada berita yang berjudul Mencuri 3 Buah Kakao, Nenek Minah Dihukum 1 Bulan 15 Hari. Hal tersebut menunjukkan peristiwa yang terjadi dalam cerpen tersebut juga terjadi di Indonesia, sehingga dekat dengan latar belakang budaya siswa.

Fenomena hukum bukanlah suatu hal yang jauh dari budaya siswa, karena Indonesia merupakan negara hukum, yang peristiwa-peristiwa hukumnya selalu diberitakan di media massa setiap hari. Meskipun siswa tidak mendapatkan pembelajaran khusus tentang hukum, namun guru dapat memberikan arahan kepada siswa untuk mempelajari fenomena-fenomena hukum melalui media massa. Siswa juga dapat memanfaatkan kecanggihan teknologi, berupa internet untuk mengetahui hal-hal tentang hukum. Penting bagi siswa untuk mengetahui budaya baru yang terdapat di negaranya. Hal tersebut akan memberikan pengetahuan baru kepada siswa.

Dari keseluruhan hasil penelitian tersebut, dapat diketahui bahwa bahwa fenomena hukum dalam cerpen Hakim Sarmin karya Agus Noor memenuhi tiga kriteria aspek pemilihan bahan ajar sastra, sehingga relevan digunakan sebagai bahan ajar teks cerpen untuk siswa kelas XI SMA. Terdapat lima data konflik sosial Lewis A. Coser, dengan rincian, tiga data konflik realistis dan dua data konflik nonrealistis yang digolongkan ke dalam tiga aspek pemilihan bahan ajar sastra, yaitu aspek bahasa, psikologi, dan latar belakang budaya.

\section{SIMPULAN DAN SARAN}

Berdasarkan hasil penelitian dan pembahasan yang telah dipaparkan pada bab sebelumnya, adapun hal yang menjadi simpulan dalam penelitian ini, sebagai berikut.

Pertama,
konflik hukum $\begin{gathered}\text { berita-berita } \\ \text { di }\end{gathered}$

menggambarkan adanya ketidakadilan hukum di Indonesia. Hal tersebut tercermin melalui putusan pengadilan yang berat sebelah. Konflik yang tercermin dalam berita tersebut, yaitu konflik realistis dan konflik nonrealistis. Terdapat empat data konflik realistis dan satu konflik nonrealistis. Hal tersebut menunjukkan adanya kecenderungan konflik realistis lebih sering terjadi dalam konflik hukum di Indonesia.

Kedua, cerpen Hakim Sarmin karya Agus Noor merepresentasikan ketidakadilan hukum yang terjadi di Indonesia. Terdapat tujuh data konflik sosial Lewis A. Coser dengan rincian dua data konflik realistis dan lima data konflik nonrealistis. Terlihat bahwa konflik nonrealistis cenderung lebih banyak menggambarkan konflik di dalam cerpen. Cerpen tersebut merefleksikan pristiwaperistiwa hukum yang terjadi di Indonesia yang tercermin dari adanya kesamaan peristiwa hukum dalam cerpen dengan kenyataan yang terjadi di Indonesia. Ketidakadilan petugas-petugas hukum dalam menangani kasus yang diceritakan dalam cerpen tersebut juga terjadi dalam kehidupan nyata.

Ketiga, fenomena hukum dalam cerpen Hakim Sarmin karya Agus Noor relevan digunakan sebagai bahan ajar teks cerpen untuk siswa kelas XI SMA, karena memenuhi tiga kriteria aspek pemilihan bahan ajar sastra, yaitu aspek bahasa, psikologi, dan latar belakang budaya. Terdapat lima data dari segi konflik sosial Lewis A. Coser, dengan rincian yaitu tiga data konflik realistis dan dua data konflik nonrealistis yang digolongkan ke dalam tiga aspek pemilihan bahan ajar sastra.

Dari analisis Konflik Sosial Lewis A. Coser, ternyata konflik yang terjadi dapat bersifat positif. Konflik dapat memiliki fungsi, baik pada konflik yang terjadi dalam kehidupan nyata maupun dalam cerpen. Konflik-konflik yang terjadi pada akhirnya dapat menyelesaikan ketegangan dan mempertahankan nilai- 
nilai, serta dapat menciptakan sebuah kesadaran dan meningkatkan interaksi dan integrasi.

Berdasarkan hasil penelitian dan pembahasan yang telah disajikan di atas sebagai simpulan, berikut adalah beberapa saran yang dapat disampaikan dalam penelitian ini.

Pertama, guru Bahasa Indonesia hendaknya dapat memanfaatkan hasil kajian ini dalam pemilihan teks sebagai bahan pembelajaran teks sastra di sekolah, khususnya pada tingkat SMA, karena hasil kajian ini relevan dengan aspek bahasa, psikologi, dan latar belakang budaya siswa, terutama dalam membicarakan hal-hal terkait dengan topik hukum. Apabila guru membutuhkan materi hukum, hasil kajian ini sangat relevan digunakan dalam pembelajaran teks sastra.

Kedua, guru hendaknya kreatif dan inovatif dalam memanfaatkan teks-teks sastra dalam pembelajaran yang tidak hanya memanfaatkan teks yang ada dalam buku ajar, namun berkembang mencari teks-teks pada media-media yang ada, sehingga akan mengarah kepada hal yang bersifat autentik dan kontekstual dengan kehidupan siswa. Autentik dalam hal ini adalah nyata dapat dipakai dalam pembelajaran teks cerpen, sedangkan kontekstual yang dimaksud adalah sesuai dengan kehidupan masyarakat Indonesia.

Ketiga, peneliti lain hendaknya melanjutkan penelitian ini, dalam aspek yang lain, karena kajian ini hanya sebatas menganalisis relevansi terhadap pembelajaran teks cerpen. Karena kajian penelitian ini, teks-teks ini juga dapat dikaji dan digunakan dalam pembelajaran struktur dan kebahasaan teks seperti yang dituntut dalam Kurikulum 2013.

\section{DAFTAR PUSTAKA}

Asyhadie, Zaeni dan Arief Rahman. 2016. Pengantar IImu Hukum. Jakarta: PT RajaGrafindo Persada.

Dawud. 2004. Bahasa dan Sastra Indonesia. Jakarta: Erlangga.
Detik.com. 2009. Mencuri 3 Buah Kakao, Nenek Minah Dihukum 1 Bulan 15 Hari.https://news.detik.com/berita/ d-1244955/mencuri-3-buah-kakaonenek-minah-dihukum-1-bulan-15hari (diakses pada 28 Mei 2019)

Is, Muhamad Sadi. 2015. Pengantar IImu Hukum. Jakarta: Prenamedia Group.

Kompas. 2010. 25 Terdakwa Korupsi Miliaran Rupiah Divonis Bebas. https://regional.kompas.com/read/ 2010/01/14/22060092/25.Terdakw a.Korupsi.Miliaran.Rupiah.Divonis. Bebas (diakses pada 28 Mei 2019)

Kompas. 2016. Cerpen Pilihan Kompas 2015: "Anak Ini Mau Mengencingi Jakarta?". Jakarta: PT Kompas Media Nusantara.

Linggar, Esa Wahyu Setyo. 2017. "Konflik Sosial dalam Novel Kambing \& Hujan Karya Mahful Ikhwan (Kajian Konflik Sosial Lewis A. Coser)".https://www.neliti.com/id/p ublications/243094/konflik-sosialdalam-novel-kambing-amp-hujankarya-mahfud-ikhwan-kajiankonflik (diakses pada 28 Desember 2018)

Sayuti, Suminto A. 2000. Berkenalan dengan Prosa. Yogyakarta: Gama Media.

Ulum, Muhammad Miftahul. 2015. "Peningkatan Prestasi Membaca Permulaan Anak Berkesulitan Belajar Membaca Menggunakan Metode Pembelajaran Kontekstual melalui Inkluisi do SDN Pajang 1 Surakarta".https://media.neliti.com/ media/publications/171552-IDpeningkatan-prestasi-membacapermulaan-a.pdf (diakses pada 18 Januari 2019)

Wendra, I Wayan. 2017. Penulisan Karya IImiah (Skripsi, Proposal, Artikel). Singaraja: Universitas Pendidikan Ganesha.

Wulansari, Dewi. 2009. Sosiologi: Konsep dan Teori. Bandung: PT Refika Aditama. 
Volume : 9 Nomor: 2, Agustus 2019

P-ISSN : 2614-4743 (cetak) dan e-ISSN : 2614-2007 (online)

Yasa, I Nyoman. 2012. Teori Sastra dan

Putra Darwati.

Penerapannya. Bandung: Karya 